\title{
ACCOUNTING AND AUDITING THROUGH THE LENS OF NON-ACCOUNTANTS: AN EMERGING ECONOMY EXPERIENCE
}

\author{
Ibrahim Khan ${ }^{1}$ and Md. Shafiqul Islam ${ }^{2}$ \\ ${ }^{1}$ MBA, Department of Accounting \& Information Systems, \\ Faculty of Business Studies, University of Dhaka, Bangladesh \\ E-mail: ibrahimkhanlimon@gmail.com \\ ${ }^{2}$ Lecturer, Department of Business Administration, \\ Faculty of Business and Economics, East West University, Bangladesh \\ E-mail: shafiqul@ewubd.edu
}

\begin{abstract}
Both accounting and auditing involve public interest and so it is important to understand the legitimacy of these fields from the point of view of the non-accountants. Therefore, this study looks at the perception of accounting among non-accountants; status of non-accounting users' understandability of accounting information; and finally, perception of non-accountants about the effectiveness of audits. Using 33 semi-structured interviews to draw common factors in the first stage and conducting a questionnaire survey among 125 participants to test the consistency of the interview results in the second stage, this study found that non-accountants, in general, view accounting as an excessively technical, less forward-looking and number crunching discipline. This study also found that non-accountant investors lack understanding of accounting reports and metrics, make trading decisions based on other sources of information and have low level of faith in accounting numbers. However, the comparability feature of accounting information tends to offset some of the decision-making barriers. Another finding of this study is that the credibility of audit reports, in general, is low among non-accountants. The role of an audit is considered an ornamental exercise. The findings show that awareness about accounting and auditing is relatively low in Bangladesh suggesting a small number of "informed users".
\end{abstract}

Keywords: accounting, audit, emerging economy, non-accountant, Bangladesh

$\underline{\text { ARTICLE INFO }}$

Article History:

Received: 17 April 2020

Accepted: 17 June 2020

Published: 31 August 2020 


\section{INTRODUCTION}

Accounting, as a part of the overall system of accountability of individuals, businesses and other groups of interests, has a social role imbedded in its origin (Bryant, Wier, \& Stone, 2006). Accounting ensures accountability to a wide range of interests and, in many cases, has been recognized as a way to facilitate credible information to interested user groups (Fowler, 1995). Despite frequently being of interest to the wider society involving various groups of people, accounting has often disclaimed its responsibility to furnish understandable information to all user groups. For example, the Conceptual Framework of IASB mentions that "Financial reports are prepared for users who have a reasonable knowledge of business and economic activities and who review and analyze the information diligently. At times, even well-informed and diligent users may need to seek the aid of an adviser to understand information about complex economic phenomena." This portrays a perception that there is an inherent difficulty for users who are neither well informed nor diligent to decipher the meaning of complex accounting information in decision making. However, a large number of people whose interests are affected by the use accounting information are non-accountants meaning they have little or no formal education or training in accounting and auditing. And to the extent accounting is considered a social activity, it is nevertheless important to understand the perception of non-accountants towards accounting in order to understand its social legitimacy (Lowe \& Puxty, 1990).

Auditing, a filed closely related with accounting, also has a social origin. In fact, it is called a demand driven discipline. A major responsibility of auditors comprises of safeguarding public interest (Monroe \& Woodliff, 1994). Therefore, how the wider society, conceive of them is of particular interest not only to practicing auditors in particular but also to the profession at large.

Considering the immense impact of image on accounting and auditing envisaged by non-accountants (referring to people with no academic or institutional accounting and auditing education or training), this study purports to find the answers to three questions from the non-accountants in Bangladesh. First, what is the perception of accounting among non-accountants? Second, what is the status of their understandability 
of accounting information? Third, what is their perception about the effectiveness of audits?

The rest of the study is organized in the following manner. Section two discusses the rationale of this study. Section three reviews the existing literature on accounting and auditing perception of society in general and among the non-accountants in particular. Section four presents an overview of the study methodology highlighting various aspects of the interviews and the survey. Section five communicates the main findings of this study. Section six discusses the implications of the findings and finally section seven, the last section, concludes the study by summarizing the important points.

\section{RATIONALE OF THE STUDY}

Both accounting and auditing serve public interest in their broadest application. To that extent, the public can be classified into two groupsaccountants and non-accountants. Accountants, in this study, comprise of all the people who have formal education or training on accounting and auditing while non-accountants have none. However, as the interest of the non-accountants in a society is also affected by accounting and auditing, it is important to know how they (non-accountants) understand and see these fields and whether there is any gap in-between. This is the prime motivation behind this study.

The rationale for choosing Bangladesh as the field of study are several. First, the country has experienced rapid economic growth in the past several years (Kamal \& Islam, 2018). This has made the country undergo a rise in economic activities along with several financial reforms. These factors have led to the increased demand and creation of roles for accounting and audit professionals. Therefore, society's perception towards these professions is an important avenue to explore in an attempt to align their interest with that of the society. Secondly, accounting and auditing has secured a strong institutional form in Bangladesh. ICAB, ICMAB, ICSB, ICAG are some of the professional bodies governing and regulating professional accountancy, auditing and related practices in this country. Some of them are internationally acclaimed with global partnerships and recognition. 
Therefore, it is of importance for them to know what the other part of the society thinks about them.

Finally, there is a dearth of academic research in Bangladesh related to the exploration of society's views of accounting and auditing. In fact, to the best of the knowledge of the author, this is the first attempt in Bangladesh to explore how non-accountants see accounting and auditing. These are the areas where the motivation of this timely intervention stem from.

This study is expected to make an impact on how the society's perception of the professions and their actual roles are to be aligned to eliminate, or at least reduce expectation gap and cognitive dissonance, if any. Also, this study provides a remedy to the lack of research in this area from an emerging economy perspective.

\section{LITERATURE REVIEW}

\section{Status of Accounting}

According to Saudagaran (2009), accounting has often been viewed as a social activity. It has been seen as a factor that influences the institutional environment of a society while it, itself, is a product of the same (Preobragenskaya, McGee, \& Komarev, 2018). Therefore, the role of accounting is to deliver information to users to facilitate informed decision making. Even though the Conceptual Framework of IASB narrows down the intended primary user base of general-purpose financial accounting information to existing and potential investors, lenders and other creditors, there is nevertheless an interaction of the entire society with accounting information. Therefore, the perception of the general people within a society with a large section of people having no academic or institutional accounting education is an important factor. This leads to several questions including how this field of knowledge and its members have contributed towards aligning their interests with the broader social interest and whether or not there exists any gap between societal expectation of the roles of accounting and what accounting has actually been performing. The identification of the gap (if any) is of particular importance because, in the long run there must be an alignment of the interest of a body of knowledge with the wider users 
of that body of knowledge to ensure it sustains the test of time (Wessels \& Steenkamp, 2009).

The view of society regarding accounting and accountants is mixed for the most part as reported by various researchers. Preobragenskaya et al. (2018) examine public perception of the role of accounting by using Russia as an example of a transition economy. They find that the public in general feel that financial statements lack reliability while companies manage earnings downwards. The study identified several potential reasons for misreporting in the Russian context. Preobragenskaya et al. (2018) conclude that the reliability of financial reporting is perceived to have a greater impact on the country's economy than on the person which implies the social role of accounting is more comprehensive than the individual role. If the perception towards accounting as a means of ensuring accountability is lost among members of the wider society, then there should be reasons to be concerned about its sustainability as a field of study as well as a profession to practice.

Hung (2014) undertook a survey of university students to examine the perceptions of accounting and accountants in China. The results show that not only Mainland Chinese but also Macau students perceived accounting as less interesting and accountants as boring and dull. Other researches also find public perception of accountants as being less innovative. However, accounting is often seen negatively as most of accounting innovation often end up in various schemes of earnings management (Wessels \& Steenkamp, 2009). In fact, the nature of accounting itself is very structured and it involves strong adherence to technical issues.

According to Wells (2017), public perception of accounting has been overly concentrated in the technical role of accounting. However, a strong focus on quantitative tools and techniques is an inherent part of accounting to ensure objectivity in the process of accountability. People in general tend to construct an image of accounting where theory and qualitative concepts are almost always undermined (Wells, 2015).

Contrary to these findings, Hung (2014) found that public view accounting as a precise and definite discipline while they conceive the profession of having a high social status in the Chinese context. Other 
researchers have also found a similar notion towards the profession concluding that the accounting profession is seen as an emblem of high social status (Gallhofer, Haslam, \& Kamla, 2009).

\section{Status of Auditing}

Auditing is perhaps the closest discipline that is linked to accounting in many respects. Auditing, by its very origin, involves a concern of public and social interest above individual interest (Navallas, Del Campo, $\&$ Miñano, 2017). The primary responsibility of auditors has changed from time to time in line with the society and legal framework view of what auditors are supposed to do. At one moment, the purpose of auditing centered on detecting frauds and errors while at later times, auditing became the responsibility of auditors to provide an opinion (reasonable assurance) on the truth and veracity of the preparation and presentation of financial statements (McEnroe \& Martens, 2017). Therefore, what image people in general construct of audits is a critical issue for this filed.

Historically, there has been deviation between the views of the public and auditors regarding the role audits should play which is termed as the audit expectation gap. To be more precise, the audit expectation gap refers to the difference between (I) what the public and other financial statement users perceive auditors' responsibilities to be and (II) what auditors believe their responsibilities involve (McEnroe \& Martens, 2001). This audit expectation gap has been prevalent in societies over years but the magnitude of the gap has been found to vary across economies. In underdeveloped and developing economies with a weak finance infrastructure and fragile culture of accountability, the audit expectation gap has been found to be higher.

Beyond the expectation gap, empirical studies have found a mixed view of society towards auditors. Some researchers find an inflated perception of public regarding the depth of auditors' pockets. However, in general, the position of auditors is found to be seen with that of a social status and dignity in most societies. Auditors have also been perceived as "skeptical and hard to convince" in nature in many studies following from their professional requirement of skepticism. However, Navallas, Del Campo, and Miñano (2017) found in a Spanish study that after an extracurricular activity with auditors, students considered auditors as more warm, 
more available to work in teams, more modest, more tender-minded, and less impulsive than before suggesting that there is a gap between perception and reality of an auditor's image.

Despite the existence of a number of studies regarding societal perception of accounting and audit in developed countries, this avenue has been mostly ignored in empirical research in developing countries such as Bangladesh. This lack of research in such an important area might be motivated by the difficulty to analyze and interpret subjective views of different people regarding accounting and audit. Hence, this study is a timely intervention to explore this avenue from the perspective of an emerging economy.

\section{RESEARCH DESIGN AND METHODOLOGY}

\section{Data Collection}

The data applied in this study came from both primary and secondary sources. Primary data were gathered from thirty-three (33) semi-structured interviews conducted with non-accountants from various roles and professions in the society as well as a questionnaire survey with 125 respondents. The secondary data used in this study came from various academic research and professional publications concerning the field of accounting and auditing. The application of interviews, questionnaire surveys and secondary research ensured the triangulation of research data and strengthened the findings.

\section{Methodology}

This study was conducted in two stages, using a number of semistructured interviews in the first stage followed by a questionnaire survey in the second stage. Interviews were arranged due to the qualitative nature of the research question which also laid the ground for the formation of the survey questionnaires. The questionnaire survey was conducted to examine the consistency of the interview results and attain greater comfort in generalizing the answers to the research questions. 
To further rationalize the decision to choose the participants stemmed from the fact that there has been a vacuum of scholarly research in Bangladesh concerning the view of non-accountants about accounting and auditing. So, it was necessary to understand through an initial interaction what factors to be included in the questionnaire survey. Which means the initial detailed interviews worked as an arrangement to support the design of the questionnaire in the second stage of the research. In that, it worked like a pilot study which brought forth the factors to work with. In the second stage of the study, a survey was conducted in order to derive the understanding and perception of a wider community of non-accountants about accounting and auditing.

\section{Interviews}

First, thirty-three (33) semi-structured interviews were conducted with non-accountants from various roles and professions in the society to address their views regarding the research questions.

Participants were chosen in order to give their perceptions about accounting and auditing which is the subject of the study concerned. It was ensured that participants came from a diverse set of backgrounds ranging from students to corporate managers so as to enable the convergence of a wider domain of perceptions and ideas. Both male and female participants were chosen from five different backgrounds served the purpose of avoiding concentration bias in responses.

The number of interviews reflect the point at which saturation in responses was achieved. The common factors stated by most interviewees were passed on to the questionnaire survey in the next stage of the research.

The interviews were semi-structured in a sense that the three research questions were preset for the interviewees while the natural flow of the conversations were also maintained within each of these three avenues. The length of the interviews ranged from thirty minutes to one hour. The responses of the interviewees were transcribed verbatim to facilitate a content analysis that captured the main themes representing the perception of the interviewees during the interview sessions. Table 1 gives the constitution of the interviewees. 
Table 1: Construction of Interviewees

\begin{tabular}{lccc}
\hline \multirow{2}{*}{ Professions of the Interviewees } & \multicolumn{3}{c}{ Number of Interviewees } \\
\cline { 2 - 4 } & Male & Female & Total \\
\hline Academics & 2 & 2 & 4 \\
Students & 4 & 3 & 7 \\
Business owners & 3 & 2 & 5 \\
Corporate managers & 6 & 4 & 10 \\
Stock market investors & 5 & 2 & 7 \\
Total & $\mathbf{2 0}$ & $\mathbf{1 3}$ & $\mathbf{3 3}$ \\
\hline
\end{tabular}

The interviewees were divided into two sections. The first section involved a brief introduction of the interviewees in terms of their name, profession, gender, age and a background query regarding previous involvement with accounting and auditing. The second and main session of the interviews comprised of a semi-structured discussion regarding the three research questions.

\section{Questionnaire Survey}

A Likert scale questionnaire comprising of thirteen (13) items was formulated to conduct the survey. The questionnaire was circulated among a sample of 200 individuals out of which 125 complete responses were received signifying a response rate of $62.5 \%$. In order to ensure that only non-accountants participated in the survey, clear instructions were given in Part 1 of the questionnaire. The items on the questionnaire were developed based on the factors derived from the interviews in the first stage of the study. The survey was conducted with the aim of examining the consistency of the interview results in a larger sample so as to facilitate greater generalizability.

The responses of the survey were quantified by assigning a Likert scale value ranging from 1 (strongly disagree) to 5 (strongly agree). Thereafter, the numeric values of the responses were analyzed using descriptive statistics and explained with graphs. The results from the interviews were explained under the broad factors derived followed by the findings of the questionnaire survey with possible explanations of the results. Finally, the major findings from both stages of the study were summarized in tables addressing the three core research questions. Appendix A provides a sample of the questionnaire. 


\section{FINDINGS}

This section depicts the findings of the interviews and the results of the questionnaire survey. The findings are presented under the three core research questions with highlights of major factors derived from the content analysis of the interviews as well as the factor analysis of the survey.

The internal consistency of the survey questionnaire consisting of 13 items, as shown in Table 2, was measured using Cronbach alpha which gave a value of 0.7367 . A value of Cronbach alpha of 0.60 or more is considered acceptable and here the value 0.7367 suggests that the construction of the items is internally consistent and the data is reliable.

Table 2: Reliability Statistics

\begin{tabular}{cc} 
Cronbach's Alpha & Number of Items \\
\hline 0.7367 & 13 \\
\hline
\end{tabular}

Table 3 presents the descriptive statistical summary of the items of the questionnaire survey. Apparently, the standard deviation in the responses of the items suggest a more generalizable result. The implications of the results on other items will be linked with the interviews and discussed as appropriate.

Table 3: Descriptive Statistics

\begin{tabular}{lccccc}
\multicolumn{1}{c}{ Items } & $\mathbf{N}$ & Min & Max & Mean & SD \\
\hline 1. Accounting serves social interest. & 125 & 2.00 & 5.00 & 3.736 & 1.0365 \\
2. Accounting appears to be interesting. & 125 & 1.00 & 4.00 & 2.192 & 0.7008 \\
$\begin{array}{l}\text { 3. I understand financial accounting } \\
\text { information. }\end{array}$ & 125 & 1.00 & 5.00 & 2.696 & 0.7180 \\
$\begin{array}{l}\text { 4. Comparability of accounting information } \\
\quad \text { useful. }\end{array}$ & 125 & 2.00 & 5.00 & 4.432 & 1.0224 \\
$\begin{array}{l}\text { 5. Accounting is objective. } \\
\text { 6. Accounting is more oriented to number } \\
\text { than theory. }\end{array}$ & 125 & 1.00 & 5.00 & 4.136 & 0.7626 \\
7. Accounting information is credible. & 125 & 2.00 & 5.00 & 4.120 & 1.1906 \\
8. Accounting is innovative. & 125 & 2.00 & 5.00 & 2.272 & 0.7197 \\
9. Audit serves social interest. & 125 & 2.00 & 4.00 & 2.120 & 0.5879 \\
& & 5.00 & 3.864 & 0.9495
\end{tabular}




\begin{tabular}{lrrrrc}
\hline \multicolumn{1}{c}{ Items } & N & Min & Max & Mean & SD \\
\hline $\begin{array}{l}\text { 10. Audit is supposed to prevent financial } \\
\text { failure. }\end{array}$ & 125 & 1.00 & 5.00 & 4.376 & 1.0093 \\
$\begin{array}{l}\text { 11. I understand audit reports. } \\
\begin{array}{l}\text { 12. Audit should play corporate policing } \\
\text { role. }\end{array}\end{array}$ & 125 & 1.00 & 5.00 & 3.680 & 0.6997 \\
\begin{tabular}{l} 
13. Audit reports are useful. \\
\hline
\end{tabular} & 125 & 1.00 & 4.00 & 3.880 & 0.6274 \\
& & & & 1.952 & 0.4355 \\
\hline
\end{tabular}

In short, the descriptive study above found that non-accountants generally view accounting as an objective yet less exciting and innovating discipline that serves social interest with much technical orientation. This is evident in the mean score obtained in the 5th item above, which is 4.136 implying that most of the participants agreed on this matter. On the opposite if the 2 nd item above is considered, the mean value is only 2.192 implying a considerable disagreement among the participants regarding the interestingness of accounting. In relation to the second research question, the study found that non-accountants found accounting difficult to understand and the credibility of accounting information was generally low (mean score being only 2.272). However, comparability, an enhancing characteristics of accounting information is of much use to non-accountants. Finally, in relation to the third research question, the descriptive study founwd that non-accountants found audits to serve social interests and have expectation gaps to the extent they expect audits to undertake a corporate policing role preventing failures. However, the usefulness of audit reports is also generally low among non-accountants.

\section{Perception of Accounting}

During the interview sessions, 22 interviewees out of 33 opined that accounting as less exciting and less challenging while 8 of them stated that they see accounting as an interesting field of study and profession from the outside. Therefore, in the questionnaire survey, one item was related to the interest on accounting of non-accountants. Besides, a great majority of the interviewees as well as the survey participants tended to perceive accounting as an extremely technical field and profession as opposed to being intuitive. 


\section{Social Interest, Objectivity and Innovation}

A major hypothesis of the study concerning the service of accounting to the society was positively reported by both the interviewees and the survey participants. A staggering number of 30 interviewees $(91 \%$ of the total) said that they believe accounting to be a profession that directly and indirectly takes part in serving the society in various capacities. Also, as much as $58 \%$ of the survey participants stated accounting to be serving social interests as shown below.

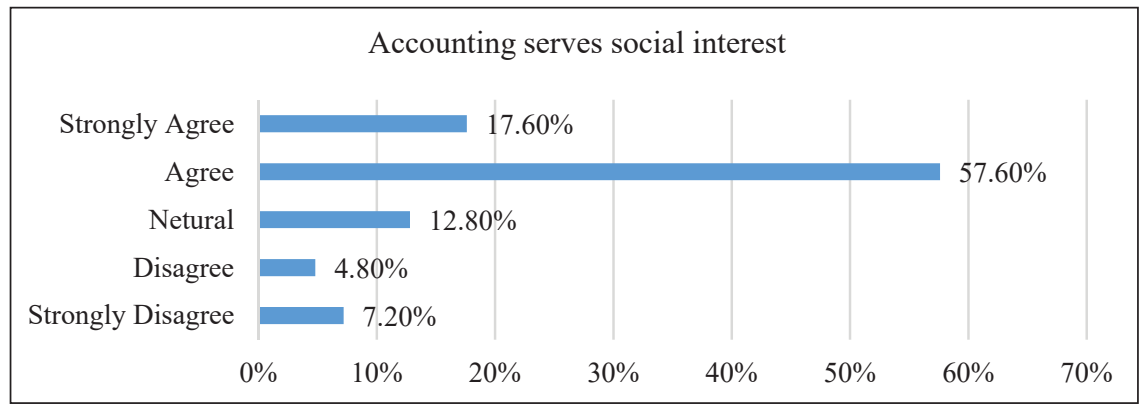

Figure 1: Result of Survey for the Interview Question

One of the interviewees put the following words concerning the social service of accounting

“...yet it will be ungrateful not to acknowledge the societal role of accounting, especially in ensuring the accountability of listed corporations which mostly trade with public money. Accounting being nonexistent, there would be no other mechanism to facilitate interaction between those corporations and the public in general"

As much as $69 \%$ of the survey participants and $54 \%$ of the interviewees said they projected accounting to be an objective discipline with little scope for improvisation therein. One corporate manager puts the following in this regard.

“...my colleagues from the accounts team are very objective and they pay attention to details. From my experience of working 
with them in a cross functional team, I can say accounting, itself appears very objective and precise to me".

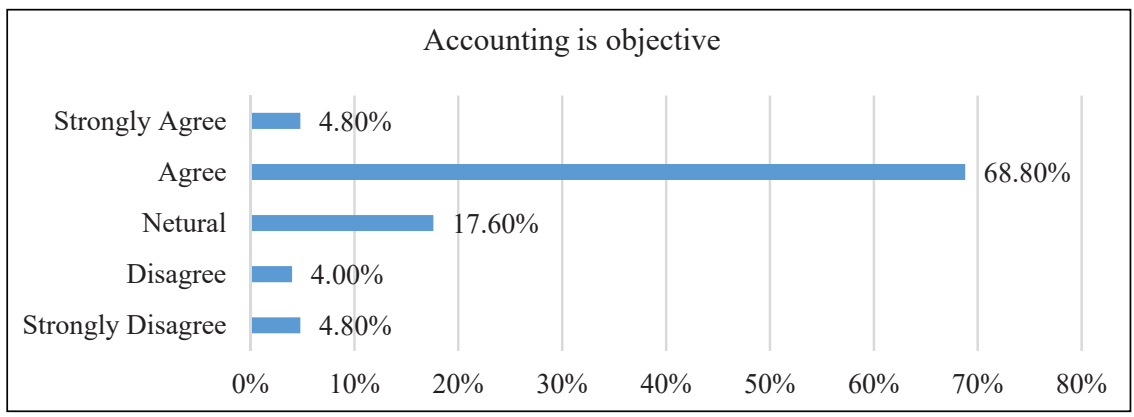

Figure 2: Result of Survey for the Interview Question

The interviewees were mostly neutral about their views of innovation in accounting. There was no identifiable consensus among them in this regard. However, the survey participants appeared to disagree that accounting is innovative with the mean response falling in between disagree and neutral.

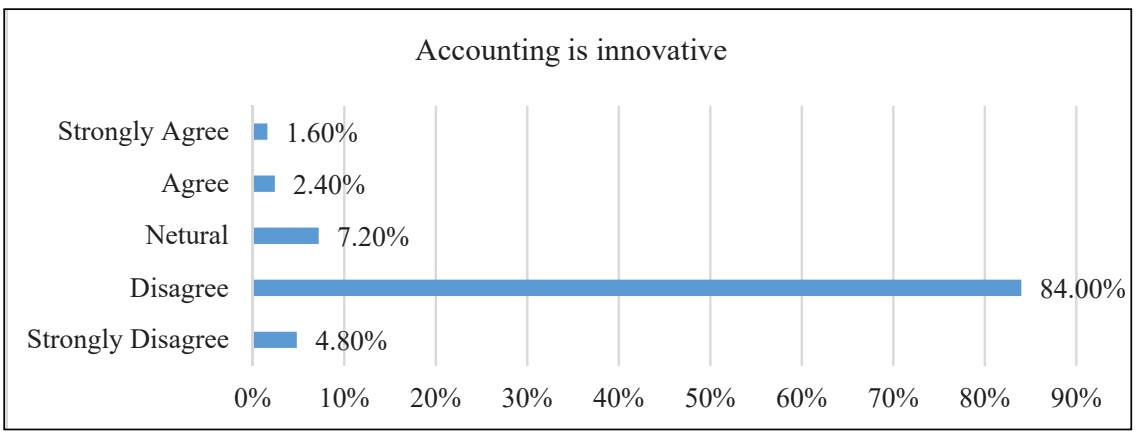

Figure 3: Result of Survey for the Interview Question

\section{Unexciting}

The projections of two-thirds of the interviewees regarding accounting is that it appears to be kind of boring and less interesting both as a subject of study and a profession. The words they used to describe accounting in terms of its appeal to them include tedious, monotonous, boring, unexciting and dull. One female academic puts the following remarks while asked to describe her perception towards accounting. 
"My husband is an academic of accounting in a public university. We worked in a joint research project involving accounting and psychology (which we couldn't finish for some reasons) whereby I came to interact with him regarding various issues in accounting and surprisingly found that accounting has been much less varied in its development over years... in fact, my husband doesn't seem to resist while I call his subject a boring one since then (of course jokingly!)"

Another interviewee, a male university student, put the following words while describing his impression of accounting as an academic subject.

".... and over the years I have come to know a lot about accounting for having to share my room (in dormitory) with a friend in Accounting major! I have seen him studying the same subject in 4 different semesters and his books on other subjects tend to outnumber his accounting books. He doesn't disagree with me that accounting is not as vast and interesting as physics (the major of the interviewee)"

The result of the questionnaire survey showed that as much as $81 \%$ of the participants disagree with the statement that accounting appears to be interesting which is quite consistent with how the interviewees described accounting from their point of view.

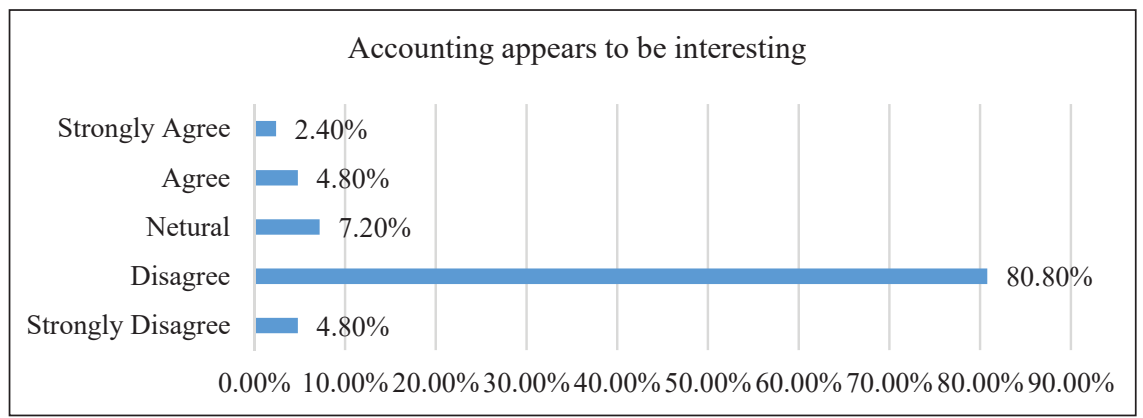

Figure 4: Result of Survey for the Interview Question

These responses are consistent with those obtained by Hung (2014) in a study of Chinese students' perception of accounting and accountants. 
They found that both accounting majors and non-accounting majors tend to rate accounting and accountants as "boring" as opposed to the adjective "interesting".

\section{Technical Emphasis}

Interviewees described their projections of accounting to be mostly technical and a number dependent exercise. They have portrayed an overwhelming view of numbers and technical analysis in accounting. One manager from the marketing department of an MNC puts the following in this regard.

".... the pictures that comes to my mind while the word accounting is concerned are numbers, numbers and numbers. I think calculations are what accountants mainly perform, at least this is what I see my colleagues from the accounts department do"

Surprisingly 20 out of 33 (around 61\%) interviewees pictured accounting in this way. Consistent with the interviewees, as much as half of the survey respondents strongly agreed that accounting has more focus on numbers than on theories.

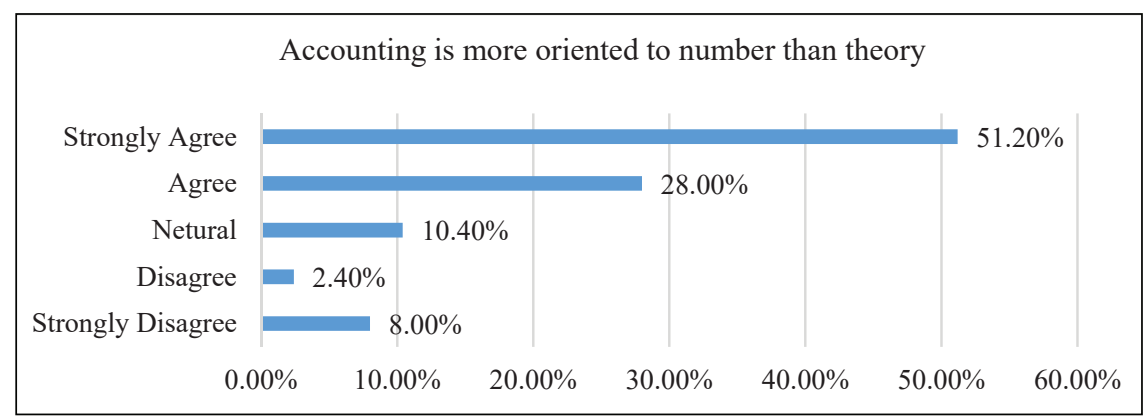

Figure 5: Result of Survey for the Interview Question

These findings are again supported by Hung (2014) where respondents rated accounting as more definite, clear, historical and precise rather than intuitive, spontaneous and forward-looking. A summary of the findings on the first research question is presented in Table 4. 
Table 4: Summary of the Findings of the First Research Question

\begin{tabular}{lcccccc}
\hline RQ 1: What is the status of accounting as perceived by non-accountants? \\
\hline \multirow{2}{*}{ Accounting } & \multicolumn{3}{c}{ Interview Results } & \multicolumn{3}{c}{ Survey Results } \\
\cline { 2 - 7 } & Agree & Neutral & Disagree & Agree & Neutral & Disagree \\
\hline Serves social interest & $91 \%$ & $3 \%$ & $6 \%$ & $75.2 \%$ & $12.8 \%$ & $12 \%$ \\
Is objective & $54 \%$ & $21 \%$ & $25 \%$ & $73.6 \%$ & $17.6 \%$ & $26.4 \%$ \\
Is innovative & $14 \%$ & $57 \%$ & $29 \%$ & $4.0 \%$ & $7.2 \%$ & $88.8 \%$ \\
Is unexciting & $64 \%$ & $19 \%$ & $17 \%$ & $85.6 \%$ & $7.2 \%$ & $7.2 \%$ \\
Is a technical exercise & $61 \%$ & $23 \%$ & $16 \%$ & $79.2 \%$ & $10.4 \%$ & $10.4 \%$ \\
\hline
\end{tabular}

In sum, the research found that non-accountants tended to see accounting as an objective and technical exercise serving social interest but yet lacking excitement and innovation.

\section{Status of Understandability of Accounting Information}

One of the findings of this study involved the view of the nonaccountants of accounting information as difficult to interpret and understand as well as not the primary basis of affecting trading decisions made by them where applicable. However, this study found that, despite being unable to adequately understand and interpret accounting information, non-accountants can attain some decision-making inputs by comparing time series changes in accounting information. This means, the comparability feature of accounting information tended to offset some of their decisionmaking barrier. However, a majority of the interviewees lacked trust on accounting information to some extent.

\section{Understandability}

Both the business owners and stock market investor groups (among the interviewees) acknowledged that they face difficulty in understanding and interpreting accounting information reported in annual reports. The interviewed stock market investors acknowledged that they do not have adequate financial literacy to comprehend complex accounting information. One of them remarked the following.

"It's been a while I am in the stock market trading but honestly, I cannot decipher the meaning of some complex metrics in the annual reports. ... as I depend on advises from my brokers and tips 
from my friends, I can deal with my lacking of understandability of accounting. And I can compare figures of profits, sales and assets to see the trends".

However, the lion's share of the survey participants expressed a neutral view with the statement that they understand accounting information. But even here, the number of participants disagreeing with this statement outnumbered those agreeing with the same. So, in a way, survey results are somehow similar to interview results regarding non-accountant's understandability of accounting information.

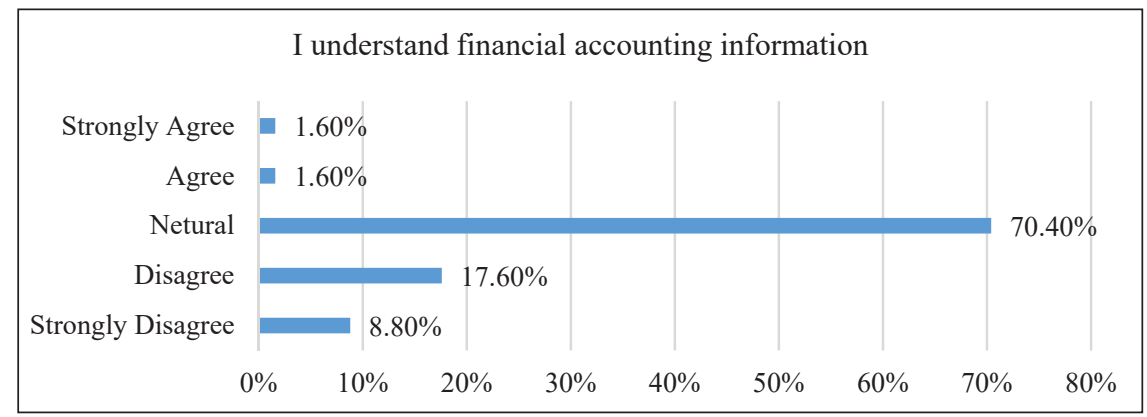

Figure 6: Result of Survey for the Interview Question

It is supported by empirical research that people with no accounting background have often faced difficulties in understanding the implications of certain accounting information (Bryant et al., 2006).

\section{Credibility and Comparability}

Around $88 \%$ of the interviewees have shown their interest in accounting numbers either in the form of direct investments (stock market and business) or indirect deposits in banks where the annual reports of the banks relate to their interest. However, interviewees of all classes have shown a general tendency to lack utmost trust in accounting information. One stock market investor said-

"I used to believe the pre-IPO accounting numbers of companies during my earlier days of stock market investment. However, after years of experience on how those pre-IPO earnings deviate 
from post-IPO scenario taken away much of my confidence on accounting numbers".

Similarly, the survey participants, with a mean response of 2.27 (lying between disagree to strongly disagree), confirmed that they did not feel accounting information to be credible.

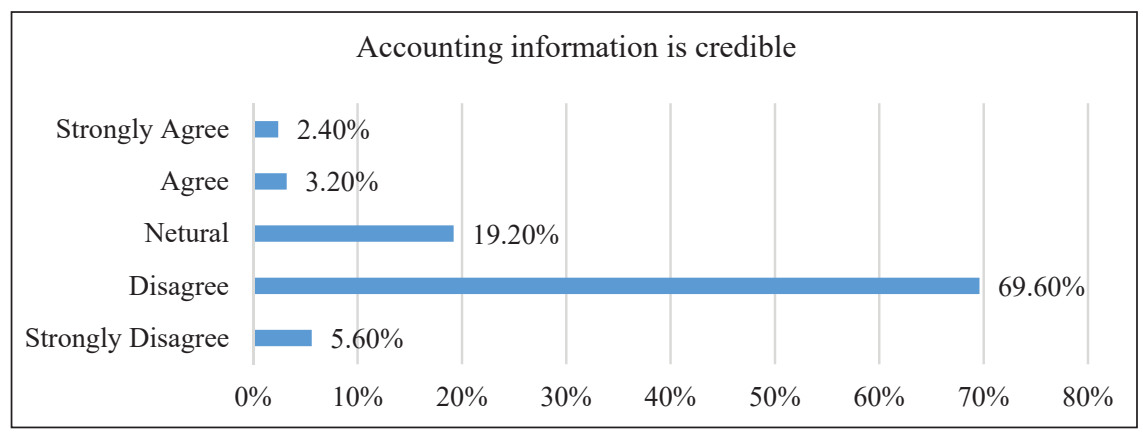

Figure 7: Result of Survey for the Interview Question

One of the business owners said:

"In hard times accountants have to manage the appearance of my business in the books but I am sure that doesn't come at the cost of ethics in my organization, but I have seen businesses unethically outperform us through window-dressing".

The lack of trust on accounting information can be explained by either a knowledge gap of the non-accountants regarding what accounting numbers signify or to the practice the practice of earnings management and low-quality accounting information in a number of business failures in Bangladesh in the recent past. Lowe and Puxty (1990) found that excessive earnings management tend to take away public faith in accounting numbers.

Despite the lack of trust, non-accountants in both interviews and survey have reported that the comparability feature of accounting information is useful to overcome some information processing barrier. In fact, almost all interviewees (from the investor category) stated that a large number of trades they made are based on a time series comparison of accounting information. Consistent with interview results, a staggering $85.6 \%$ of 
survey participants confirm the usefulness of the comparability feature of accounting information as shown below.

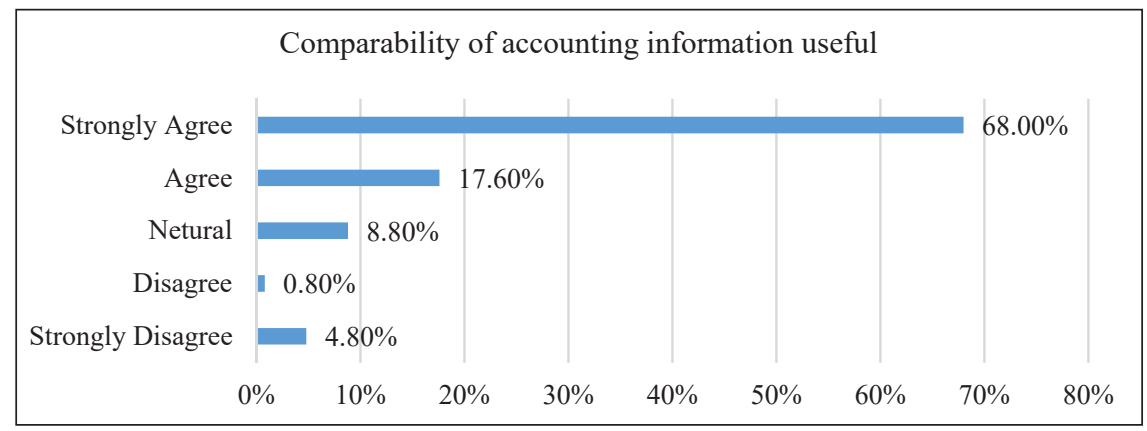

Figure 8: Result of Survey for the Interview Question

A summary of the findings on the second research question is presented in Table 5.

Table 5: Summary of the Findings of the Second Research Question

\begin{tabular}{lcccccc}
\hline \multicolumn{3}{c}{$\begin{array}{c}\text { RQ 2: What is the status of non-accounting users' } \\
\text { understandability of accounting information? }\end{array}$} \\
\hline \multirow{2}{*}{$\begin{array}{c}\text { Accounting } \\
\text { information is }\end{array}$} & \multicolumn{2}{c}{ Interview Results } & \multicolumn{2}{c}{ Survey Results } \\
\cline { 2 - 7 } & Agree & Neutral & Disagree & Agree & Neutral & Disagree \\
\hline Difficult to understand & $56 \%$ & $31 \%$ & $13 \%$ & $75.2 \%$ & $12.8 \%$ & $12 \%$ \\
Credible & $26 \%$ & $21 \%$ & $53 \%$ & $5.6 \%$ & $19.2 \%$ & $75.2 \%$ \\
Useful with comparability & $59 \%$ & $23 \%$ & $18 \%$ & $85.6 \%$ & $8.80 \%$ & $5.6 \%$ \\
\hline
\end{tabular}

In sum, the research found that non-accountants find accounting information difficult to understand and tended to base their trading decision on other sources of information. But comparability turns out to be useful in overcoming the decision-making barrier while general credibility of the accounting information was low.

\section{Perception of Audit}

This study found that there is high level of consensus among nonaccounts in terms of the social service of audits. $66 \%$ of the interviewees and $82.4 \%$ of the survey participants found that audits directly or indirectly fulfil a broader social cause. However, almost all the interviewees as well 
as the survey participants had a massive audit expectation gap where they have shown signs of lost credibility due to not even knowing that audit reports can take various forms. Besides, the interviews revealed that nonaccountants in general mistake audits as having a corporate policing role and auditors as corporate police.

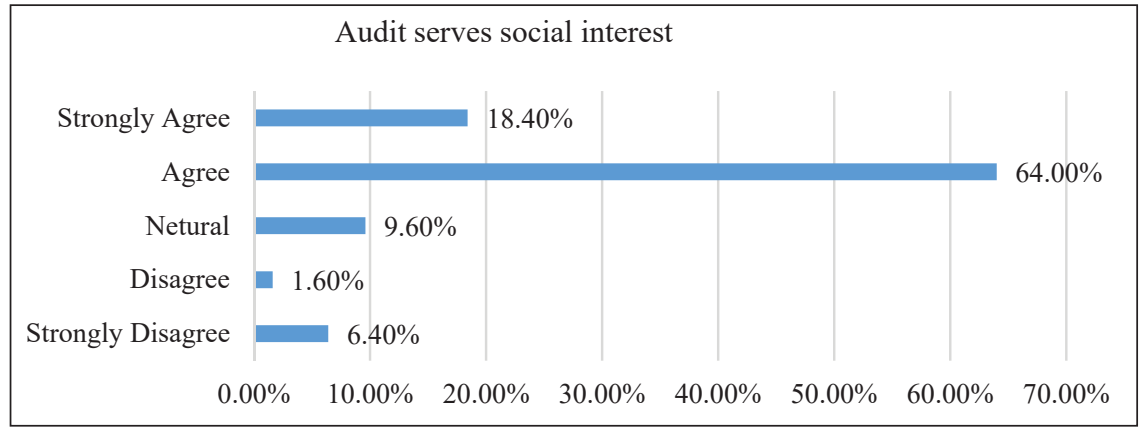

Figure 9: Result of Survey for the Interview Question

\section{Expectation Gap}

All the interviewees failed to recognize the actual role of audits which is to opine on the truth and veracity of the financial reports. Almost all of them have expressed an expectation from an audit that is far beyond reasonable assurance and stretches to absolute level of assurance. One corporate manager put the following statement regarding his perception towards the effectiveness of audit.

".... therefore, to the best of my understanding we mostly have our reports audited due to compliance issues rather than efficiency reasons. I do not even know how these audits have added value to our organization, if any at all."

Similar to the interview results, survey participants massively disagreed on the usefulness of audit reports as shown in the graph below. 


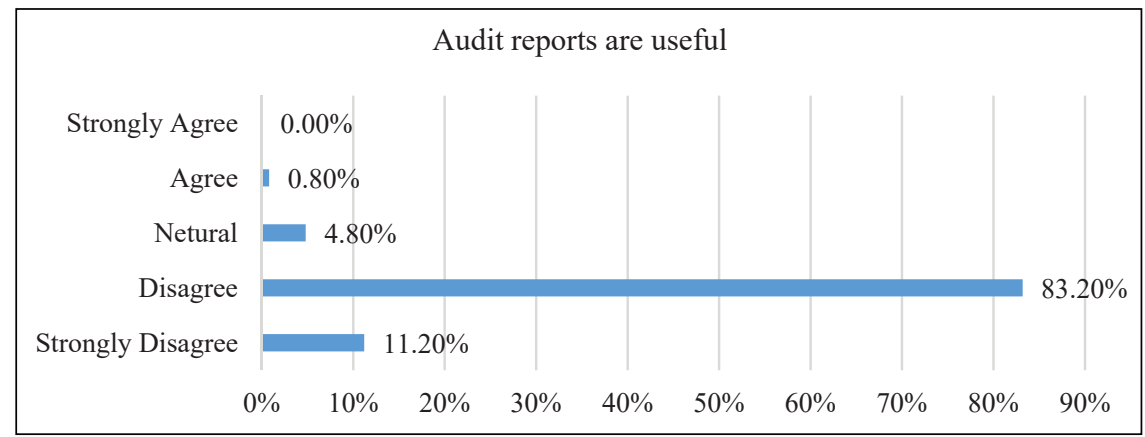

Figure 10: Result of Survey for the Interview Question

Another corporate manager pointed out:

"...take Hallmark or Sonali Bank scandals for example. Were those companies not audited in the years they came out as failures? I don't see audit to be much effective then!"

This is clearly a misunderstanding from the non-accountant's part while auditors explicitly disclaim their liability to prevent frauds and corporate failures and accept the responsibility to only opine on the truth and fairness of the subject matter against criteria. This expectation gap was highlighted in the survey results as presented in the graph below.

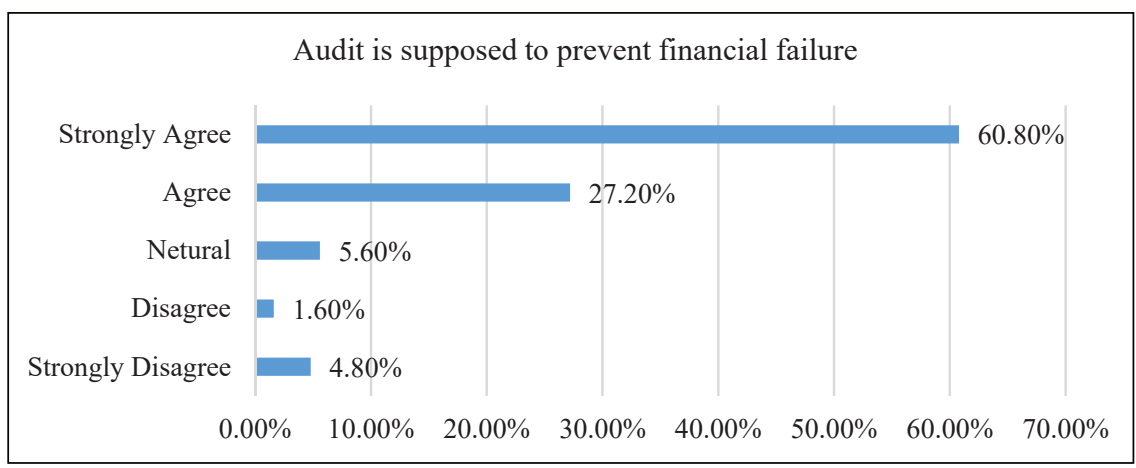

Figure 11: Result of Survey for the Interview Question 


\section{Policing Role}

The role of audit as envisaged by the non-accountants involves a strong adherence to the responsibility of preventing, detecting and communicating financial frauds, errors and accounting irregularities. One corporate manager mentioned the following in this respect.

“...there have been three dismissals in the cash department embezzlement in the last two years alone. However, our auditor has turned out to be ineffective in preventing such embezzlements".

From the interviews it was clear that the non-accountant managers held the audit function liable for not being able to prevent fraud. He effectively has a policing image of the audit function. Similarly, survey participants agreed that audits should play a corporate policing role. This finding is consistent with Monroe and Woodlif (1994).

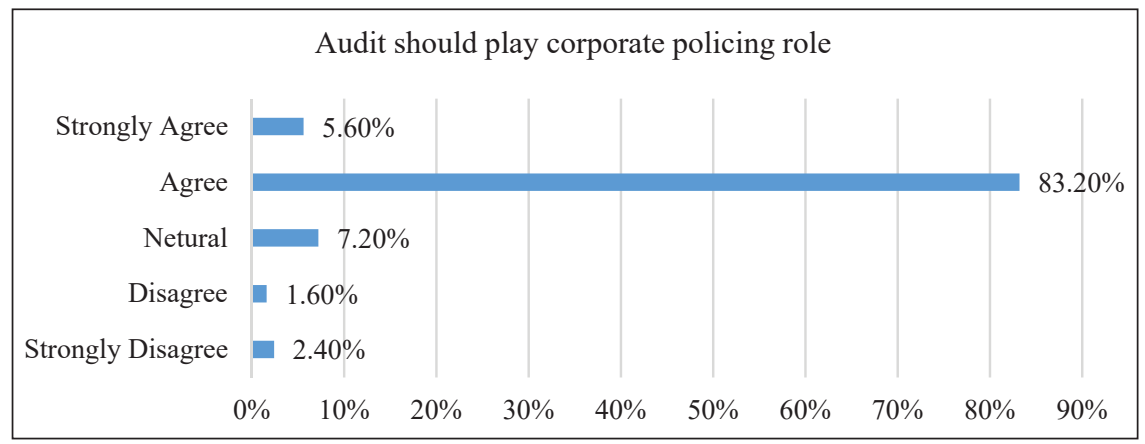

Figure 12: Result of Survey for the Interview Question 
A summary of the findings on the second research question is presented on Table 6.

Table 6: Summary of the Findings of the third Research Question

\begin{tabular}{|c|c|c|c|c|c|c|}
\hline \multicolumn{7}{|c|}{$\begin{array}{l}\text { RQ 3: What is the perception of non-accountants } \\
\text { about the effectiveness of audits? }\end{array}$} \\
\hline \multirow{2}{*}{ Audit } & \multicolumn{3}{|c|}{ Interview Results } & \multicolumn{3}{|c|}{ Survey Results } \\
\hline & Agree & Neutral & Disagree & Agree & Neutral & Disagree \\
\hline Serves social interest & $66 \%$ & $41 \%$ & $13 \%$ & $82.4 \%$ & $9.6 \%$ & $8.0 \%$ \\
\hline Provides useful reports & $23 \%$ & $21 \%$ & $56 \%$ & $0.8 \%$ & $4.8 \%$ & $94.4 \%$ \\
\hline $\begin{array}{l}\text { Should prevent } \\
\text { corporate failures }\end{array}$ & $72 \%$ & $11 \%$ & $17 \%$ & $88.0 \%$ & $5.60 \%$ & $6.40 \%$ \\
\hline $\begin{array}{l}\text { Should play corporate } \\
\text { policing role }\end{array}$ & $79 \%$ & $13 \%$ & $8 \%$ & $88.8 \%$ & $7.2 \%$ & $5.0 \%$ \\
\hline
\end{tabular}

After all these discussions it is clear that non-accountants tended to view audit as socially important but had a massive expectation gap regarding the roles of audits where they think the audit reports are not useful and that audits should assume a corporate policing role to prevent corporate failures. Findings from the initial interview closely correspond to those of the descriptive study.

To sum up, this section of the paper discusses the results of both the interviews and the descriptive study under three broad heads- perceptions of accounting, status of understandability of accounting information and perception of audit. Each of these subsections corresponds to the three research questions addressed throughout this study. Table 3 presents the summarized results of the descriptive study at one place while Table 4, 5 and 6 present the findings of the descriptive study corresponding to each of the three research questions.

\section{DISCUSSION}

The findings of the study have several implications. First, non-accountant interviewees tended to hold an image of accounting where it is conceived of as a field of study as well a profession that lacks innovation, is monotonous, dull and unexciting. Also, they have a belief that accounting is much more 
technical than a forward-looking exercise, is definite, clear and precise. This shapes their view that there is low scope for flexibility in this rigid field. This perception can be changed by incorporating more recent developments in the field of accounting to practice. Integrated reporting, environmental accounting, carbon accounting, and other innovations of accounting should be encouraged for application to avert this view of non-accountants.

Second, the status of the understandability of accounting information is low in general among the interview participants. Such non-accountants fall beyond the locus of "informed users" mentioned in the Conceptual Framework. They tend to rely more on the comparability feature of accounting information. The credibility of accounting numbers is generally low among them and they have to rely on other sources of information for trading decisions. The understandability of accounting information can be enhanced by incorporating qualitative and visual reporting paralleled with quantitative reporting.

Third, despite agreement regarding the social service of auditing, the credibility of the audit function was low among interview participants and awareness about the possibilities of alternative audit reports other than the unqualified report was almost absent. More research is required for finding ways to diminish the expectation gap in this area.

Finally, considering the overall situation it was found that the general level of awareness of accounting and auditing is low in Bangladesh among non-accountants and further research is needed to devise ways in order to align public perceptions with the realities of accounting and auditing.

\section{CONCLUSION}

This study sought to answer three questions. First, what is the perception of accounting among non-accountants? Second, what is the status of nonaccounting users' understandability of accounting information? Third, what is the perception of users with no accounting knowledge about the effectiveness of audits? In answering these questions, this study chose Bangladesh as the field of investigation to be a proxy of developing economies. The country's recent elevation of economic activities and rapid 
growth combined with developments in the financial sector, presence of several accounting bodies and the dearth of research in this area justify Bangladesh as the place of the study. Using semi-structured interviews and secondary research, this study found that interviewed non-accountants, in general, viewed accounting as a number crunching discipline, excessively technical and less forward-looking. This paper also found that laymen investors do not understand accounting reports and metrics, make trading decisions based on other sources of information and have low level of faith in accounting numbers. However, the comparability feature of accounting information tended to offset some of the decision-making barriers emerging form difficulty in understanding and interpreting accounting information. Another finding of this paper is that the credibility of audit reports, in general, was low among non-accounting users of financial statements as most of them have not seen any variation in such reports over years. The role of audits is considered to be an ornamental exercise. The findings suggest that accounting awareness is very low in Bangladesh and a narrow base of "informed users" follow from this deficiency.

\section{REFERENCES}

Bryant, S. M., Wier, B., \& Stone, D. N. (2006). Accounting stakeholders' perceptions of accountants' job performance and motivation. Available at SSRN 912994.

Fowler, H. E. (1995). A history of the public's perceptions of accountants. University of Tennessee Honors Thesis Projects. Retrieved from https:// trace.tennessee.edu/utk_chanhonoproj/115

Gallhofer, S., Haslam, J., \& Kamla, R. (2009). Educating and training accountants in Syria in a transition context: Perceptions of accounting academics and professional accountants. Accounting Education: An International Journal, 18(4-5), 345-368.

Hung, K. S. (2014, January). Perceptions of accounting and accountants in the eyes of the people from Mainland China and Macau. Paper presented at the 2014 International Conference on Global Economy, Commerce and Service Science (GECSS-14). Atlantis Press. 
Kamal, Y., \& Islam, M. S. (2018). The paradox of foreign loans and grants: An econometric analysis in the perspective of Bangladesh. Dhaka University Journal of Business, 39(3), 51-66.

Lowe, T., \& Puxty, T. (1990). Accounting as social science: Some implications for teaching and research. Directions, 12(1), 54-72.

McEnroe, J. E., \& Martens, S. C. (2001). Auditors' and investors' perceptions of the "expectation gap". Accounting Horizons, 15(4), 345-358.

Monroe, G. S., \& Woodliff, D. R. (1994). Great expectations: Public perceptions of the auditor's role. Australian Accounting Review, 4(8), 42-53.

Navallas, B., Del Campo, C., \& Miñano, M. D. M. C. (2017). Exploring auditors' stereotypes: The perspective of undergraduate students. Revista de Contabilidad-Spanish Accounting Review, 20(1), 25-35.

Preobragenskaya, G., McGee, R. W., \& Komarev, I. (2018). Public perception of the role of accounting in a transition economy: The case of Russia. International Journal of Accounting, Auditing and Performance Evaluation, 14(4), 338-363.

Saudagaran, S. M. (2009). International accounting: A user perspective. Chicago: $\mathrm{CCH}$.

Wells, P. (2015). Looking in the mirror. Pacific Accounting Review, 27(4), 486-507.

Wells, P. (2017). How does contact with accountant's influence perceptions of accounting? Accounting Education, 28(2), 127-148.

Wessels, P. \& Steenkamp, L. (2009). An investigation into students' perceptions of accountants. Meditari: Accountancy Research, 17(1), 117-132. 


\section{APPENDIX A}

\section{Survey Questionnaire (Partial View)}

Part 1: Qualifying Test for Part 2 and Part 3

1. Do you have any academic or professional education or training on accounting or auditing?

2. Are you familiar with accounting?

3. Are you familiar with auditing?

4. Have you interacted with accounting information?

5. Have you interacted with auditing information?

If the answer of question 1 is No and questions $2-5$ is yes, ONLY THEN proceed to Part 2 and 3; otherwise please do not proceed further.

Part 2: Accounting

Strongly

Disagree

Disagree Neutral

Agree Strongly

Agree

Accounting serves social interest.

Accounting appears to be interesting. I understand financial accounting information.

I find comparability of accounting information useful.

Accounting is forward-looking.

Accounting is more number oriented

than theory oriented.

Accounting information is credible.

Accounting is innovative.

Part 3: Auditing

Audit serves social interest.

Audit is supposed to prevent financial failure.

I understand audit reports.

I think audit should play corporate

policing role.

Audit reports are useful. 